\title{
CAMILLE PAGLIA'S SEX, ART, AND AMERICAN CULTURE
}

\author{
Sue O'Sullivan
}

Camille Paglia's writing is often numbingly boring. The problem with reviewing her is that selective quotes make her appear snappy in a fashionably politically incorrect way. Then Camille the public performer and Camille the writer of books get all mixed up. Which is not to say reading Sex, Art and American Culture is only boring; it is also infuriating. I kept looking ahead to see how much more, oh lord, how much more to go before I was through? Then there were the moments of disgust and anger. And why didn't anyone warn me in one of the numerous hyped-up articles I read about naughty Camille that her writing is repetitious and tediously predictable? I'm bewildered that Paglia has apparently captivated so many with so little, including a swag of gay men and lesbians. In a recent issue of the Australian gay magazine Outrage, Peter Blazey practically elevated our Camille to saviour status (Blazey, 1993). It just goes to show, yet again, that being queer is no indicator of political acumen.

At least her first book; Sexual Personae - Art and Decadence from Nefertiti to Emily Dickinson, no matter how nauseously undergraduate it tended to be, did focus on famous cultural artifacts and personalities. In it she tells us she is practically single-handedly rescuing us from the aridity of modernism and restoring the unity and continuity of Western culture in an approach which combines the disciplines of literature, art history, psychology and religion. Gee whiz. Her 'method is a form of sensationalism: I try to flesh out intellect with emotion and to induce a wide range of emotion from the reader' (1992: xiii). The aim is continued in this collection of essays, mostly written between 1990 and 1992 after the first book's publication. In it she expounds ad infinitum on her main themes, including the news that rape is one of life's little miseries, that paganism and astrology are deep and meaningful, that American academia sucks, French intellectuals suck, feminism sucks, lesbianism sucks, Madonna is fabulous and so is PAGLIA. But the focus 
is narrow and the weaknesses of her position in relation to popular culture are clearer than in Sexual Personae.

Let me make it clear from the start that I am not opposed to Paglia because she: (a) is in favour of pornography; (b) supports sadomasochism but makes sure we know she doesn't practice it; (c) adores gay men; (d) thinks Madonna is the bee's knees; (e) wore Lauren Hutton's Wonderbra for a photo opportunity; (f) is an academic; (g) can't get anyone to fuck her; $(h)$ calls herself a Freudian. All of these might form the basis for an energetic and humorous self-engrandizement. I loathe her because of the positions she takes about nature, society, men and women, politics, rape, sexuality, feminism, gay men, and religion and I am critical of Paglia's world-view because of its incredibly reactionary basis.

Paglia claims all sorts of (magnificent) things for herself. She is going where no one else has dared. She reveres Freud. She will reclaim 'Catholicism's ancient, latent paganism' (42). She will persuade us (endlessly) of the inevitable 'Apollonian versus Dionysian dichotomy in the West' (151). She will restore the primacy of never-changing Nature to our understanding of sex. She will ram common sense down our throats. She will make raucous fun of date rape. She will explain that rock and roll heralds democracy. She will extol her 'Sixties generation' (47) (over and over) and she will tell you often of Paglia's unique greatness and astuteness when it comes to popular culture. She is also saving feminism from the spoilsport, whiny, middle-class women's studies' academics and their wussy male counterparts on campuses all over America. Each and every one of these places is apparently in the grip of a sorority of po-faced Lacanian, leftist, liberal, anti-pleasure women.

Paglia is pissed off by wishy-washy Rousseauian humanists but she makes sure that we understand that being anti-liberal does not mean she is a neo-conservative. However, just because someone tells you something continuously does not for one second mean that they are telling the truth or achieving what they claim to. Paglia is transparently a libertarian conservative. She doesn't seem to be able to comprehend that it is entirely possible to be pro sex, pro porn, pro abortion, pro prostitution and be a conservative. Has she never heard of libertarian Tories? Hasn't she got a clue that her much vaunted voices of 'realism' and 'common sense' are exactly those of a variety of conservatisms. The woman is chillingly naive about politics - about political history, currents and analysis.

Paglia is usually out of date, behind the times, and definitely not in tune with the streets. She wouldn't know a street if it hit her in the face. It's embarrassing. Her analysis of modern culture is banal and relies heavily on descriptive passages referring to theories, famous traditions, historical buzz words. Because it is posed as central to everything, culture tends to loom. She makes a meal out of how much perversity excites her. OK, OK. But she comes across as mean spirited, not as someone interested in taking wing herself. It's as if she has watched American popular culture for the past two or three decades from a 
college room, from a distance, never from within it. You can imagine her in her student personae as the neurotic swot whose main social intercourse is always with 'mentors' and teachers, covering her needy arse with condescending dismissals of her peers. Yeah, maybe it is a bit sad, but Christ do we have to suffer her as a consequence?

Camille is as vacuously reductive in her boring denunciations of 'the feminists' as any feminist has ever been in her denunciation of patriarchy. Both rely on blanket assertions which ignore the subtle and complex ways in which women have struggled with different feminisms for over ten or fifteen years, acknowledging and analysing the different ways feminists see the world and try to change it. But if she did that she couldn't make the outrageous statements which send the press and anti-feminists into paroxysms of joy. Paglia's style and content depend on selection and wilful ignorance.

As far as Paglia is concerned, feminists make women into victims and attack her for giving women responsibility. 'I am being vilified by feminists for merely having a common-sense attitude about rape' (59). A big lump of this common-sense attitude includes the fact that, 'We cannot regulate male sexuality. The uncontrollable aspect of male sexuality is part of what makes sex interesting. And yes, it can lead to rape in some situations. What feminists are asking for is for men to be castrated, to make eunuchs out of them. The powerful, uncontrollable force of male sexuality has been censored out of white middle-class homes' (63). She finishes off this astoundingly silly section by throwing out a backhanded racist 'compliment' to two groups who she claims haven't censored male sexual lust by saying, 'But it's still there in black culture, and in Spanish culture' (63).

Camille has long, recurring diatribes about hormones, biology and sex differences. She has the audacity to claim that as well as being a Freudian, she is not a biological determinist. Listen to the lady: 'Dionysus, trivialised by Sixties polemicists, is not pleasure but pleasure-pain, the gross continuum of nature, the subordination of all living things to biological necessity' (105). And, 'My theory of nature follows Sade rather than Rousseau: aggression and violence are primarily not learned but instinctual, nature's promptings, bursts of primitive energy from the animal realm that man has never left' (105). She ruminates on why society 'works': 'Despite crime's omnipresence, things work in society, because biology compels it' (107).

Contrary to Paglia's claims, she is about as Freudian as a fried egg. Quite the opposite: she has no deep understanding of those concepts and continuously misrepresents or contradicts her supposedly Freudian understanding of sex. For instance, in her rush to attack anything with a French whiff to it, from Rousseau to Lacan, she gives us an amazingly unreflective potted history: 'At midlife, I now accept that there are fundamental sex differences based in hormones' (107). As a 'fractious adolescent battling the conformist Fifties' she believed sexual differences were 'nothing but convention'. However, 'slowly, step by step, decade by decade, I was forced to acknowledge that even a woman of 
abnormal will cannot escape her hormonal identity'(107). It is her earlier 'noisy resistance' which has brought her 'full circle back to biology. From my militant history comes a conviction of self-knowledge: I can declare that what is female in me comes from nature and not from nurture' (107). Like the hoary ex-communist of the Cold War, Camille trots out her surface 'experiences' to lend credence to her turncoat assertions; there is not a shred of evidence that she has explored the murkier aspects of her psyche. What would a true Freudian analyst make of her?

I won't quote the excessively long paragraphs about 'woman's maternal fate' where I'm afraid that we all (with the exception of one, guess who?) end up in a swamp, engorged, immobilized, gurgling about racial memories while partaking of primal soup. 'From puberty to menopause, women are hormonally mired in the liquid realm to which this book gives the peculiar name the "chthonian swamp", my symbol for unregenerate nature'(109). No such healthy diet for men! Paglia emotes that, 'Male lust, I have written elsewhere, is the energising factor in culture. Men are the reality principle. They created the world we live in and the luxuries we enjoy. When women cut themselves off from men, they sink backward into psychological and spiritual stagnancy' (24). After this description it is clear that feminists want too much. 'But feminism was always wrong to pretend that women could "have it all". It is not male society but mother nature who lays the heaviest burden on women. No husband or day-care center can ever adequately substitute for a mother's attention' (89).

Paglia is a woman, but she clearly believes she is not like any other woman. She is more like a man. Except that she is a woman. Poor old Paglia. Now, at the middle point in her rather secluded life she experiences rampaging young men as moving and exciting. Did she ever really know any of the masculine jocks she loves to describe as inhabiting USA college campuses? Pre-feminism, in the same American 1950 s and early 1960s she describes, I and my sexy girlfriends did. We avoided them like the plague - brains the size of peas, interests confined to football, and sexual desires about as dark and demonic as fish fingers.

What is it in all this which attracts some gay men? Well, perhaps they are simply conservative. However, I also wonder if it is Paglia's self-proclaimed love of gay men which gives the clue and the libertarian points of her politics. Describing the anti-porn positions of American feminists Andrea Dworkin and Catherine MacKinnon which Paglia has attacked, Peter Blazey in his Outrage article says:

Paglia denounces both as Stalinists of political correctness, 'fanatics, zealots and fundamentalists of the new feminist religion. Their alliance with the reactionary, anti porn far right is no coincidence.' This is relevant to Australia, where feminism is becoming reflexively anti male, humorless and sexphobic; it is particularly suspect on the issue of pornography - which ought to alarm every gay male, since nothing decent ever came out of being in bed with Fred Nile. 
I quote Blazey at length because he appears to buy into Camille because she loves gay men and makes convenient sweeping nasty statements about women and feminists. The irony of this is that there are large numbers of lesbian feminists in Britain, the United States and Australia who have fought long and hard and often successfully against Dworkinite-style politics.

Does Camille's supposed adoration of homosexuality hold up under scrutiny? What does she really have to say about them? On religion this:

When feminism and gay activism set themselves against organised religion, they have the obligation to put something better in its place. Hostile intrusions into church services, as undertaken by gay groups in New York and Philadelphia, are infantile, damaging the image of gays and bringing their cause into disrepute. All sacred places, pagan or Christian, should be honored. ... Gays must face the fact that, unlike other minority groups, they cannot reproduce themselves. Like artists, their only continuity is through culture, which they have been instrumental in building. Therefore when, by guerrilla tactics, they attack the institutions of culture (including religion), they are sabotaging their own future.

(Paglia, 1992: 36)

How revolutionary. 'Our problem is not patriarchy but, in the urban industrialized world, collapsing manhood, which male homosexuality properly remedies by its glamourous cult of the masculine' (36). With a friend like this who needs enemies?

Paglia refers admiringly to the work of John J. Money, an exponent of the 'Born That Way' school of sexual difference, who has been the subject of much detailed criticism. She sets him up in opposition to Foucault, her French bête noir: 'For thirty years, the sexual territory between biology and psychology has been far more successfully and sensibly explored on American soil, at the Johns Hopkins University School of Medicine, by John J. Money' (180). And later she asserts quite uncritically that 'The Seventies and Eighties have seen a worldwide resurgence of research into hormones, comparative anatomy, genetics, fetal development, and brain chemistry, and their relation to sex differences and even personality traits' (185). This is a writer who maintains she is a Freudian.

Paglia's position on AIDS is quite similar to the one she holds on rape. The world is full of continuous and universal truths. Nature, dark and extremely messy, simply is, like it or lump it. Religion, ethical codes, morality, all are imposed by society. If you rebel against rigid or stultifying aspects of society, even if for 'good' reasons, well good luck, but don't come crying and snivelling when you get serious flack, rape, pillage, lynchings, vigilantes - or AIDS - in response. What is society? Society simply is, hey nonny no. 'We asked why should I obey the law? and why shouldn't I act on every sexual impulse? The result was a descent into barbarism. ... And out of the pagan promiscuity of the 
Sixties came AIDS. Everyone of my generation who preached free love is responsible for AIDS' (216). Later when our Pag is lighting into Foucault again she says 'If what I have reliably heard about his public behaviour after he knew he had AIDS is true, then Foucault would deserve the condemnation of every ethical person' (230).

Paglia has no sense of today's changing sexual scene except through the worship of Madonna. She claims that 'Homosexuality, more common as well as more visible, is part of this movement for sexual selfknowledge and self-definition' (99), in a paragraph which puts the boot into Seventies androgyny. But she has no understanding or knowledge of the new waves of sex and gender politics manifest in the groping but often wild and funny queer politics. Quite hysterically she criticizes the American Absolutely Queer posters of a few years ago. "Absolutely Queer." Absolutely queer? I thought we got rid of absolutes! .. . Now we've got gay people talking about what is absolute? This is fascism! This is fascism!' (276). She doesn't seem to have a clue that the juxtaposition of 'absolute' and 'queer' contains quite wittily a critique of any notion of absoluteness.

I cannot bear to go into Camille's ludicrous ideas about lesbianism which leave dykes sunk 'backward into psychological and spiritual stagnancy'. Lesbian sex is 'cozy' and the girls often end up 'in emotion without sex'. Paglia sometimes claims that she is playing games when she makes remarks like this. But I think it's another instance of her wilful ignorance. Who on earth does she hang out with - if anyone? She whinges about the impossibility of having hot sex with lesbians. My guess is that Camille is incapable of having hot sex, full stop. Gay men on the other hand are 'guardians of the masculine impulse. To have anonymous sex in a dark alleyway is to pay homage to the dream of male freedom' (24). This is extremely tired, old stuff; there is nothing new in any of this crap.

Paglia is prepared to extrapolate wildly on the nature of human existence, the meaning of sex, the causes of violence and rape, from an eccentric but selective look at art, writing and culture through history. It is the extrapolations which infuriate. The way they are juxtaposed is sometimes startling but there is nothing new in the content. And Paglia simply ignores huge chunks of history. She ignores the immensely important movements of women's liberation and Black liberation in the 1970 s. She rarely speaks convincingly or with any passion about race or class except to vilify white, middle-class women (she's Italian so none of that counts for her), or to throw out condescending compliments to African-Americans and Hispanics (Paglia talking about rape as white middle-class women's complaint: 'I don't notice so many Hispanic women and African-American women going around and carrying on like this' (268)). They know what real sex is. They don't complain about date rape. Anorexia doesn't affect them. They like food. They've got such energy. Their music is so great. Surprise, surprise, these are Camille's attributes too. Camille is loud; therefore she gets on with AfricanAmericans. 'Now I'm loud. Did you notice? I'm very loud. I've had a hell 
of a time in academe. This is why I usually get along with AfricanAmericans' (271). Wow - a new approach to race relations.

Paglia's own Pagliamania might be forgiven if she delivered the goods. Even her much touted cheekiness palls after the first chapters, especially as her deep conservatism reveals itself more and more. Surely not all her readers are so ill read and ignorant of history, feminism, politics, and popular culture that they see no flaws, hear no faux pas and smell no bullshit coming off her? Surely not all gay men, or pro pornography, pro abortion, anti-censorship readers will get cozy with Camille simply because she supports these things. In the end I am left with her monumental pretentiousness and bad style sense. Speaking for the nth time about 'my Sixties' Camille proclaims: 'My generation, inspired by the dionysian titanism of rock, attempted something more radical than anything since the French Revolution' (216). Please.

\section{References}

BLAZEY, Peter (1993) Outrage Melbourne No. 116 January, 44-7.

PAGLIA, Camille (1990) Sexual Personae - Art and Decadence from Nefertiti to Emily Dickinson Yale University Press. (1992) Sex, Art, and American Culture London: Viking. 